ing and excellent treatment, all of which will be conducive to rapid recovery. The conditions here for the successsul treatment of the fever cases are, in my opinion, far better than in any of the large hospitals in cities. It is to be hoped that the entire camp will be vacated in from four to five weeks, as after that time the soil will be thoroughly infected, in spite of all precautions, and the indigenous spread of typhoid fever would follow as an unavoidable sequence. The surgical work consists in the treatment of large abscesses, occurring in patients whose general health has been undermined by disease, or the hardships of the campaign, and operations for hemorrhoids and rectal fistula. Unjust and unnecessary criticism has a demoralizing effect on those directly or indirectly concerned. It is prone to intimidate and confuse those who are criticised and embolden those who look for undeserved sympathy. In this camp there is no further ground for complaint of any kind. It is generally known that the Medical Department was not consulted in locating the camps. For reasons known only to those in power, the camps were selected regardless of sanitary conditions. Our troops have been exposed to malaria since they left the State camps, and almost every man shows evidences of more or less malarial poisoning. As the essential cause of malaria enters the body by inhalation, malaria could not be avoided as long as the camps were located on a soil which breeds the plasmodium. Typhoid fever made its appearance in the State camps and followed the army to Chickamauga, Tampa, Alger, Cuba and Porto Rico. It is a repetition of what has happened during all campaigns under similar circumstances. Let the national cry subside now and let the press and people await the results of a thorough investigation by Congress, which will place the responsibility for any mismanagement where it belongs. The Med. ical Department courts such investigation, fully confident that the blame will be fixed outside of its legitimate jurisdiction.

Camp Wikoff, Aug. 31, 1898.

\section{OUR RELIEF SOCIETIES.}

BY N. SENN, LIEUT.-COL. U. S. V. CHIEF OF OPERATING STAFF WITH THE ARMY IN THE FIELD.

War, pestilence, famine, floods and other great national calamities, are the most reliable tests to bring out the true philanthropic spirit of individuals as well as of nations. The good Samaritan is to be seen everywhere under ordinary conditions on his errands of mercy, following the footsteps of his Master in bringing comfort to the poor, the sick, the maimed and the oppressed, but his energies are taxed to the utmost, and his work is appreciated most keenly, when the masses are in distress. The American people are noted for their charitable disposition, and have gained a well-deserved reputation for humanitarian work. Our numerous ideal charitable institutions speak for themselves. Many national catastrophes have demonstrated the liberality and good-will of our people. The War of the Rebellion furnished an interesting object lesson to the outside world of the way in which patriotism is estimated here. During the war just ended many different relief societies have rivaled with each other in supplying our soldiers, sick and well, with many comforts of life beyond the limit of the government supplies. The government itself set a noble example by sending to the camps and the invading armies all kinds of supplies, unparalleled in quantity and quality in the history of the country. I am sure no one regrets more keenly than the government officials that these liberal supplies did not always reach their destination in time. The work of the many auxiliaries corrected many of these defects. Individuals as well as organized societies have labored incessantly and faithfully in coming to the aid of the government, in furnishing the troops with underclothing and delicacies usually beyond the reach of armies when engaged in active warfare. Miss Anabel Clarestes, a little girl in Lagrange, Ill., has been busy ever since the war commenced in preparing and sending to camps and the front home-made jellies, the product of her own hand. She had no difficulty in collecting money to purchase the necessary materials, but it was left for her to labor in the humble kitchen to prepare the incomparable delicacies for the soldiers in the field. This little American girl is a heroine worthy of the praise and admiration of the returning heroes who have been benefited by her modest, unselfish work. Many a patriotic woman, unknown to newspaper notoriety, has done her share in minimizing the sufferings of this war. It was not an uncommon thing for officers to receive a box containing the contributions of some female friend of the army who sent all she could spare for the alleviation of the troops in the field. In many such instances the name of the benefactress remained unknown to those who benefited by her donation. I have opened many such boxes, containing as a rule underclothing, bandages, reading and writing material, towels, handkerchiefs, and a few jars of jelly or canned fruit. The soldiers who were made the recipients of these gifts felt that they were remembered at home, an assurance which contributed much in intensifying their patriotism and in sustaining their courage under the most trying circumstances. The intense interest manifested by the government and the people in the care and comfort of the returning army remains unequaled in the history of our country. Every soldier was met with a reception given to an intimate and long-lookedfor friend. The sick received the most tender care from all sides, and the well were given food that reminded them that they had reached home. The hospitals and many private houses threw the doors wide open to receive those who required medical treatment. Transportation home was made easy and comfortable by the active intervention of thousands of friends who were strangers when the troops left for the seat of war. In all large cities committees were organized to look after the comforts of the returning troops. In short, it may be safely stated that no army ever received a more enthusiastic, kind and cordial reception than the troops that have reached us from the seat of war.

RED CROSS SOCIETY.

Miss Clara Barton, President of the American Red Cross Society, has performed her onerous duties during the entire war with a devotion and earnestness that merit universal recognition at home and abroad. She has been tireless in her efforts to bring comfort to the soldiers at times when her services were most needed. The Texas and the little steamer Red Cross, under her command, made their appearance at Siboney at a time when outside help was most appreciated. Ice, medicines, dressings and hospital supplies were freely distributed among the sick and wounded. 
After the surrender of Santiago the Texas was the first vessel to enter its harbor on its errand of mercy in bringing food for the hungry Cubans and delicacios for the sick of the victorious and vanquished armies. The Red Cross Society established supply depots in all of the large camps and the good work done everywhere will live in the memories of all who were engaged in the conflict. Miss Barton has the confidence of the American people and she has sustained it through the present war by the thoughtful and timely distribution of the innumerable and liberal donations to the society she so well represents. An appropriate idea of what this Society has done can be gained from the fact that in Camp Wikoff alone two thousand dollars of supplies are distributed daily. Miss Barton has been assisted in her widespread humanitarian work by a large staff of physicians and nurses who came to the relief of the medical officers at times when their services were most needed. After peace was declared, Miss Clara Barton immediately sailed for Havana to bring much-needed aid to the starving reconcentrados of the long-besieged city, while her numerous helpers continued their faithful work in the home camps. The work of the Red Cross received the moral and substantial support of the charitably disposed citizens throughout the United States and liberal donations from abroad. Recent experience has again demonstrated that this society is the most important auxiliary in war as well as other natural disasters in bringing prompt relief to the sufferers.

WOMEN'S PATRIOTIC RELIEF ASSOCIATION, NEW YORK.

This benevolent Association has extended its work from the camps to the needy families of soldiers who enlisted and went to the front, leaving families behind them, worthy objects of well-deserved charity. It was founded in the City of New York at the outbreak of the war, at the residence of Mrs. Egbert Gurnsey, with Mrs. Howard Carroll as president and wellorganized committees and ad'. sory board, consisting of prominent business and professional men. The Association has provided food and house rent, as well as medical attendance, monthly, to no less than 2444 families. A free eatinghouse was established at 711 Eighth Avenue, where these families received food and clothing. Mrs. Charles Carroll, a member of the Association. was made president of the Naval Reserve Relief, and by contributions and a garden party given at her residence in New Brighton, Borough of Richmond, the sum of $\$ 2500$ was secured, which was expended for the benefit of the New York Naval Reserves. This special function of the Association did much for the comfort and efficiency of this otherwise neglected branch of the military service. The hospital work of the Association has been under the management of Mrs. Charles Carroll, Mrs. Adolph Tscheppe and Mrs. Seymore. The ladies of the Association, with Mrs. William McDonald as chairman, gave an outing to the convalescent soldiers from the different hospitals in Central Park, which proved to be one of the most memorable occasions in the annals of the history of this famous park. Mrs. Charles Carroll and Mrs. Tscheppe erected a tent in Camp Wikoff when the soldiers from Cuba commenced to return, and have been busy in distributing without any red tape an enormous amount of most valuable contributions among the sick and convalescents. Their donations of different stimulants and artificial waters have proved most acceptable and timely. From this tent ice cream has been furnished daily. A special meszenger has done excellent service in distributing mail and in looking up soldiers inquired after by anxious relatives. So fertile have been the resources of this modest little tent that it has been designated "The Gold Mine." Mrs. Tscheppe represents the ladies of the "Liederkranz," and her popularity among the Germans of New York has brought not only the most liberal donations but likewise cash in large amounts. Only the other day she received from a single source a check for $\$ 500$, which she was asked to use at her own discretion in the care of the sick and convalescent in the camp. The German press of New York has used its influence in supplying Mrs. Tscheppe with ample means on her errands of mercy.

\section{ILLINOIS ARMY AND NAVY LEAGUE.}

This relief association was organized soon after war was declared. It is composed of representative men and women throughout the State of Illinois, with head. quarters in Chicago. The secretary, Dr. F. H. Wines, had an extensive experience in dispensing charity throughout the War of the Rebellion, and was consequently well prepared in assuming the laborious and trying duties of his office. While it was the principal intention of the association to look after the interests and comforts of the State Volunteers, many of the contributions reached soldiers outside of the Illinois troops. The State of Illinois, and the City of Chicago in particular, have been very active in minimizing the inevitable sufferings incident to active warfare by sending to the camps and the front large quantities of the most desirable articles of diet, delicacies, underclothing and medicines. The League made special arrangements for transportation at reduced rates, so that the donations reached their destination promptly and at small expense. The League has had from the very beginning a handsome bank account, and cash was sent to different points for the purchasing of the most necessary articles. The citizens of Illinois will have the satisfaction of showing that by concerted action of the members of the League the work of charity and benevolence has been accomplished in the most satisfactory manner.

MASSACHUSETTS VOLUNTEER AID ASSOCIATION.

There has been an impression prevailing among the regular troops, that while the soldiers of the regular army have fought the hardest and have been sub. jected to the greatest privations, they have not received the recognition to which they are entitled, and have been more or less ignored by the different relief associations. There is undoubtedly some truth concerning these statements. The Massachusetts Volunteer Aid Association has recognized the validity of this complaint, and has directed its surgeons toward correcting the oversight. The work of this association in this direction has been particularly notable in Camp Wikoff. A number of ladies representing this Association came to the camp, and have done all in their power to render the soldiers belonging to the regular army comfortable and happy.

A light diet kitchen was established, provided and equipped at the First Division Hospital, in charge of Major Wood, in conjunction with the Red Cross Society, under the superintendency of Mrs. M. H. Willard. The kitchen is an ideal one, and is presided over by a competent chef. Mrs. Dininger is the lady mana- 
ger. The bountiful donation for the sick of the Regular Infantry Division was brought to the camp by Mrs. Leach, wife of Major Smith S. Leach, of the Engineer Corps of the Regular Army, and was contributed by the ladies of New London, Conn., and the Pequot Society. It consisted of a well-assorted collection of soups, eggs, lemons, oranges, butter, crackers, sugar, barley, cocoa, farina, beef, ham, corn-starch, codfish, breakfast food, chocolate, gelatin, tobacco, pipes, keg of whisky, writing and reading material, towels, pajamas, night-shirts and underclothing. The light-diet kitchen is one of the attractions of the camp. The relief societies that I have mentioned are only a few of the hundreds organized throughout the United States for the same purpose, notably among them the "Daughters of the Revolution" and the "Colonial Dames," all of which did their good share in alleviating the sufferings of our army in camp and at the front. The charity that has been practiced so bountifully and so generally during the present war, must satisfy our victorious army that the patriotism they carried into the field has been cultivated at home in words and action to a degree and extent unparalleled in the history of the world. War in a just cause begets patriotism, and nothing can demonstrate this more clearly and forcibly than our experience in the field and at home during the last five months.

[C Camp Wikoff, Sept. 8, 1898.

\section{SOCIETY PROCEEDINGS.}

\section{Society of Ophthalmology of Paris. Meeting of July 7, 1898.}

[Translated by Dr. Fuavel B. Trffany, Kansas City, Mo.]

M. Boucheron, vice-president, in the chair.

M. A. DARIER presented a paper on

GOME THERAPEUTIC INDICATIONS FURNISHED BY THE BACTERIOLOGIC EXAMINATION OF CONJUNCTIVAL SECRETIONS.

Several years ago, a short time after the works of Neisser, I made a series of researches in the endeavor to determine under what conditions the gonococcus produces the grave, virulent form of ophthalmo-blennorrhea. During two years I submitted to microscopic examination the secretion of almost all the conjunctivites who presented themselves at the clinic of my master, Abadie. I was able to acquire thus the conviction that there is no true purulent ophthalmia without gonococci but all gonococcic ophthalmias are not equally virulent. There are involved special questions of individualities both on the part of the patients as well as upon the part of the microbes themselves. Now the microscopic examination gives us only an approximate indication, which, moreover, the clinical observation, for a long time practised, procures us in a degree equal if not superior. So for several years I have renounced as a basis for therapeutic indications, the searching for the pathogenic microbes from the ecreting affections of the conjunctiva. I would not say as much of the pseudo-membranous conjunctivitis in which the serotherapie is of a wholly different action, according to serotherapie has to do with the Loeffler bacillus or with streptococcus. Now at this moment I am very greatly interested in the study of the therapeutic efficacy of a new salt of silver, the protargol. The results which I have obtained from this agent prota favorable that I could only confirm the conviction by bringing irrefutable anatomic and clinic proofe, so I caused to be undertaken by Mr. Valengon, my chief of clinic, a series to microscopic researches for confirming the diagnosis clincally put forth. From these studies, which will very soon be given, in an inaugural thesis, I can already draw the following conclusions, which are, moreover, the very same which I had already put forth from simple clinical observation.

1. Acute catarrhal conjunctivitis characterized by the presence of the bacilli of Weeks is cured generally in two or three days by the daily cauterizations of protargol.

2. Subacute conjunctivitis with diplobacilli (of Morax) is at first rapidly ameliorated; but relapses are so much the more frequent in proportion as the time between the cauterizations is extended. Moreover, at the end of a certain time, it comes about that, as with the nitrate of silver, a sort of accustoming to it, and the action of the medicament becomes, so to say, null and void. It is necessary to change the treatment. Following Mr. Morax, I have tried the sulphate of zinc, but I have not been very well satisfied with it. On the other hand I have been well pleased in these cases with the use of the acetate of lead, and with ichthyol 1/10 whether in solution or pomade.

3. Gonococcic purulent conjunctivitis seems to be the affection called upon to draw forth the most brilliant results from the protargollic medication. I sought to give the reason for this in two previous works. (See the Clinique Ophthalmo. logique, 1898, Nos. 1 and 6.) Up to this time in all the purulent ophthalmias which I have treated for seven months by protargol I have not seen one in which the suppuration has not been dried up at the end of a few days by bi-daily cauterizations, and that, too, in the most virulent forms. But if one ceases the reatment before fifteen days the suppuration reappears.

4. In two cases of acute pseudo-membranous conjunctivitis, non-diphtheretic, the protargol, contrarily to nitrate of silver, has led in three or four days to a complete disappearance of the false membranes. What effect would be obtained in the forms truly diphtheretic? I shall occupy myself ultimately with blepharo-conjunctivitis with trachoma and with dacrycystitis.

Mr. VALUDE-Gonococcus does not always produce the same form of ophthalmia. I observed lately in a family of five cases one only presented a grave purulent conjunctivitis, the others were only affected in a slight degree, and all, nevertheless, had gonococci in the secretions. It is then very important to find a means of diagnosticating the gravity of the affection, and this is what I hope to find in the researches of Dr. Darrier.

Mr. Sulzer--The gonococcus is not the sole agent capable of producing purulent ophthalmia, as the remarkable descriptions of Larrey on the subject of Egyptian ophthalmia (seasonable or climatic gonococcus) prove.

Mr. PARENT-I am surprised that Mr. Darrier employs still in certain grave conjunctivites (and consequently susceptible to ulcerations) the solution of acetate of lead, which exposes to metallic deposits not only upon the ulcerated parts but even in certain cases upon the conjunctiva, where it is deposited under the form of little grainy particles. Then, too, when our therapeutic arsenal is so rich in astringent and caustic substances, of what use is it to employ acetate of lead, which presents such inconveniences? When one speaks of purulent conjunctivitis, it is necessary in point of view of the gravity and the efficacy of treatment to make a difference between the adult and the baby. In general the latter is less grave and not so liable to corneal complications. It is then, for the more rapid cure of blenor. rheal ophthalmia of the adult that we must establish the superiority of protargol over other treatment, and especially over nitrate of silver. For, as to purulent ophthalmia of the baby, one may cure it (if the child is cared for immediately) by many different medications, and that with sensibly the same results. Another important point to know is the following: Does it dialyse or diffuse in the conjunctiva more deeply than nitrate of silver, and above all than of silver (naissant)? An excellent therapeutic agent recommended about fifteen years ago by Dr. Sedan, the iodid of silver (naiseant) is formed in the cul-de-sac even by the double decomposition of alkalin, iodin and salt of silver introduced into the cul-de-sac, by means of two glass bipets. In the point of view, especially, of the dialysis or of the thorough penetration of the deep layers, this iodin d'argent (naissant) presents some advantages, and I call the attention of Mr. Darrier to it that he may experiment comparatively with protargol.

Mr. SPeville-I have employed protargol only in catarrhal ophthalmia, and have obtained excellent results from it in such cases. Purulent opbthalmia of the new-born is not so benign as M. Parent would have it, and for that I have eeen recently two cases of babes treated with free washings with permanganate, who came back to me with both cornex quite gravely compromised.

Mr. MoraX - It is very easy to convince one's self that all conjunctivites with purulent secretions are not due to gonococcus. The conjunctivitis produced by the bacillus of Weeks often presents a purulent secretion. It may even be accom. panied by corneal lesions, as I have demonstrated, and on this subject I recall the case of a patient who had been attacked by an intense, acute contagious conjunctivitis with the bacillus of Weeks, which presented from the very first days of af fection, and before the beginning of treatment, quite a grave corneal lesion, since it left after it a central leucoma, and $M$. Darrier had to make ultimately an optical iridectomy. The eyes of this patient had objectively the aspect of a purulent conjunctivitis, but I repeat we had not to do with the gonococcus, but with the bacillus of Weeks. I believe that I have demonstrated that the classification of conjunctivitis based 